International Journal of Social Science and Economic Research

ISSN: 2455-8834

Volume: 05, Issue: 06 "June 2020"

\title{
RATCHET EFFECT AND RETIREMENT AGE IN THE STATE OF KERALA IN INDIA: AN ANALYSIS
}

\author{
Lenny Elsa Varghese
}

\begin{abstract}
Master of Arts in Economics with UGC NET,
Mahatma Gandhi University, Kerala, India
\end{abstract}

DOI: 10.46609/IJSSER.2020.v05i06.004 URL: https://doi.org/10.46609/IJSSER.2020.v05i06.004

\begin{abstract}
The retirement age of state government employees of Kerala is at a lower point of 56 years. It is crucial for the state with the highest literacy level and most number of qualified population to adopt a subtle strategy to keep the ageing, yet fit to work population gainfully employed in the labour market without restricting the job opportunities of the youth. Political opposition to a progressive rise in retirement age is widespread in Kerala. Associating ratchet effect and retirement age is significant in the present scenario of globalization and distinguished lifestyle as the employees become accustomed to the living standards they have maintained over the previous decades. The state of Kerala with the highest life expectancy of 74.9 years demonstrates the fact that the age 55 years is too young to be laid-off from work.
\end{abstract}

Keywords: Retirement age, Living standards, Ratchet effect, Life expectancy

\section{Introduction}

It is important to notice that with the advent of time, innumerable changes occur in the pattern of life globally. The period of 1951-60 marked the life expectancies at birth for male and female at birth to be 44.2 and 48.1 years respectively. This figure has advanced to 72.2 years and 78.2 years during 2011-15. This paper seeks to identify the shortcomings of the present retirement age wherein experienced professionals are laid off at an age where higher productivity and efficiency would have been contributed at the peak age of 56. Unlike the previous generations who were considered to be in the ageing population by the age of 45 , retirement age fixed at 55 was a normal phenomenon. At the present era of delayed marriages and pregnancies, employees retire from work while their children are still at the dependent stage. 


\section{International Journal of Social Science and Economic Research}

ISSN: $2455-8834$

Volume: 05, Issue: 06 "June 2020"

\section{The ratchet effect}

A significant part of Duesenberry's relative income hypothesis is that when income of individuals or household falls, their consumption expenditure does not fall much. This is termed as the ratchet effect. The reason being explained is that people often try to maintain their consumption at the highest level explained earlier. This is partly due to the demonstration effect which emphasises relative income as a determinant of consumption. The relative income hypothesis suggests that individuals or households try to imitate or copy the consumption levels of their neighbours or other families in a particular community (demonstration effect).

\section{Cross examining ratchet effect with retirement phase}

Duesenberry pointed out that during depression, when income falls consumption does not fall much. People attempt in their own way to protect their standard of living by:

- Borrowing

- Reducing their accumulated wealth

However it is evident that as the economy gradually moves through the cycles of recovery and prosperity, along with rise in income, level of consumption also rises. People use a portion of their income earned to either repay the debt they have created or to restore the old saving rate. Thus a lack of symmetry is being observed in people's consumption behaviour.

At the time of retirement, the employees would be finding it difficult to reduce their level of consumption with dependent children by their side. The levels of education attainment in the state is so high that by the time the parents retire, children would still be at that stage where they are attaining still higher levels of education. It would obviously take time for these educated masses to find a suitable role in the job market. 


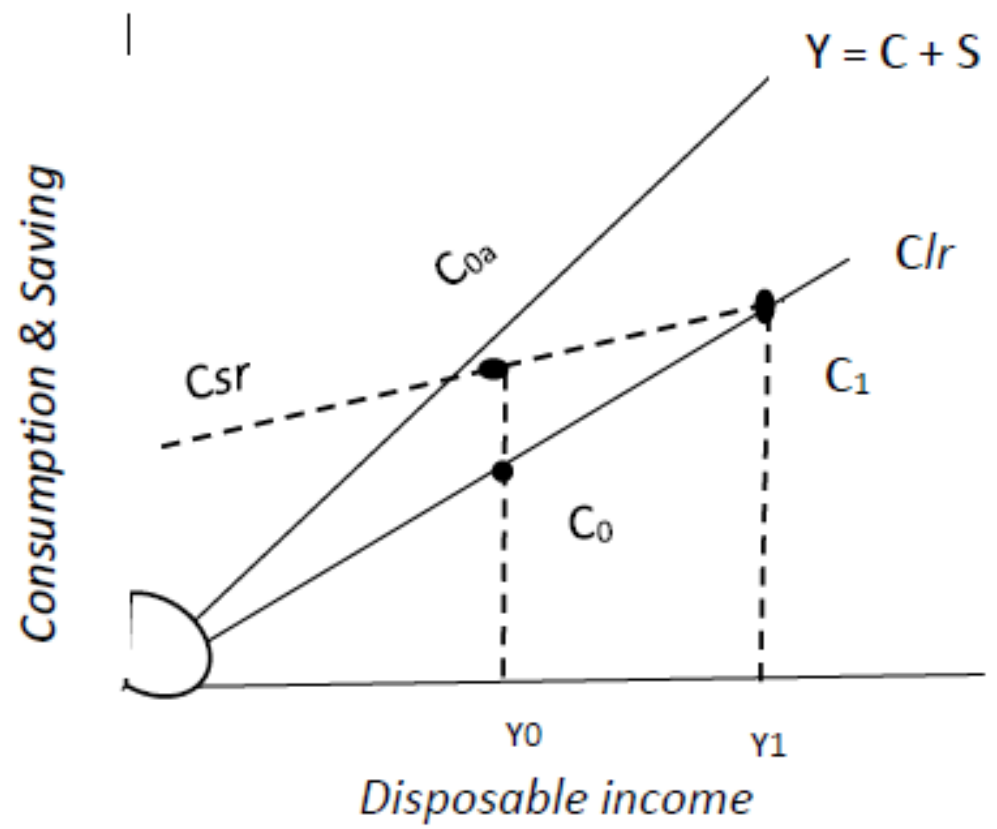

This effect is tried to explain through the above figure wherein the $\mathrm{X}$ axis measures disposable income and consumption and savings are measured on $\mathrm{Y}$ axis. At a disposable income of zero, we assume that throughout the working years say till $\mathrm{Y} 1$ there is a steady growth in disposable income. $\mathrm{Cl} r$ is the long run linear consumption function of the employee in the job market. At Y1 level of disposable income, consumption expenditure equals Y1C1. Considering that at Y1, the person has retired from his/her job which results in a fall of income to the level Y0, due to the presence of ratchet effect consumption would not fall to $\mathrm{Y0C} 0$ as the $\mathrm{Clr}$ suggests. People would now be saving less and reducing their level of consumption slightly to $\mathrm{YC} 0 \mathrm{a}$ where $\mathrm{COa}$ is on the short run consumption function $\mathrm{Cs} r$. Thus average propensity to consume at income level $\mathrm{Y} 0$ is greater than $\mathrm{C}_{1}$ at the level of income $\mathrm{Y} 1$.

\section{Choice of portfolio and life post retirement}

Private wealth holdings usually assume three forms viz net worth, net financial assets and housing equity. Total debts constitute the sum of mortgage debt, business debt added with other debt. Housing equity is obtained by computing the value of the owner-occupied house deducting the remaining mortgage debt. At the time of retirement, the bank loan on the property would still be in the pending stage (to be repayed) coupled with other burden like children's education , health emergencies and economic risks. The lifestyle being followed all the previous years will thus be continued even if it is through more borrowing in the hope that it could be repayed once the situation eases out; say when the children get employed or through the new business which has been started post retirement by the person. 


\section{Intertemporal choice: implication in the present economic scenario:}

Intertemporal choice is an economic term which explains how an individual's current decisions affect what options become available in the future. Theoretically, by not consuming today, consumption levels could increase significantly in the future, and vice versa is the essence put forward by this term. At present it is seen that people do not fshift their present needs to a considerable extend and they do live a comfortable lifestyle fulfilling their day to day needs which makes the current study relevant. Thus due to the presence of ratchet effect overweighing the occurrence of intertemporal choice among employed masses the life after early retirement at about the age of 56 troubles a whole new group of people every year financially and mentally.

\section{BIBLIOGRAPHY}

Coile, C., \& Milligan, K. (2009). How household portfolios evolve after retirement: The effect of aging and health shocks. Review of Income and Wealth, 55(2), 226-248.

French, E., Doctor, P., \& Baker, O. (2007). Asset rundown after retirement: The importance of rate of return shocks. Economic Perspectives, Federal Reserve Bank of Chicago 3rd Quarter, 49-65.

Thomas, B., Muttikkal \& James, S., Kuriath. (2014) Changes in mortality and human longevity in Kerala: are they leading to the advanced stage? PMC 